\title{
Infection Dynamics of Fusarium mangiferae, Causal Agent of Mango Malformation Disease
}

\author{
E. Gamliel-Atinsky, A. Sztejnberg, M. Maymon, H. Vintal, D. Shtienberg, and S. Freeman
}

First and second authors: Department of Plant Pathology and Microbiology, Faculty of Agricultural, Food and Environmental Quality Sciences; The Hebrew University of Jerusalem, P.O. Box 12, Rehovot, 76100 Israel; first, third, fourth, fifth, and sixth authors: Department of Plant Pathology and Weed Research, Agricultural Research Organization (ARO), the Volcani Center; P.O. Box 6, Bet Dagan, 50250, Israel.

Accepted for publication 9 February 2009.

\begin{abstract}
Gamliel-Atinsky, E., Sztejnberg, A., Maymon, M., Vintal, H., Shtienberg, D., and Freeman, S. 2009. Infection dynamics of Fusarium mangiferae, causal agent of mango malformation disease. Phytopathology 99:775781.

Conditions affecting germination and growth of Fusarium mangiferae, causal agent of mango malformation disease, were studied in vitro. Both conidial germination and colony growth required temperatures $>5^{\circ} \mathrm{C}$ and reached a peak at 28 and $25^{\circ} \mathrm{C}$, respectively. A minimum 2-h wetness period was required for conidial germination, reaching a peak after $8 \mathrm{~h}$ of wetness. High incidence of fungal colonization in buds, predominantly the apical buds, was detected compared with inoculated leaves. The

disease were not observed, either. Dry, malformed inflorescence debris serving as a source of inoculum caused significantly higher colonization (52 and 20\%) of inoculated buds, compared with that $(0 \%)$ of the untreated controls. Incidence of sampled leaf disks bearing propagules of $F$. mangiferae from an infected orchard peaked in June and July and decreased during the following months, whereas airborne infections on 1-month-old branches was the highest in May and June, corresponding with inoculum availability released from infected inflorescences. Colonization pattern, determined in naturally infected vegetative and woody branches, was significantly higher in node sections than in the internode sections. This study sheds light on infection dynamics, colonization patters, and the disease cycle of $F$. mangiferae in mango.
\end{abstract} pathogen was detected in the roots of inoculated soil 19 weeks postinoculation but not in aboveground parts of the plants, and symptoms of the
Additional keywords: Aceria mangiferae.
Mango malformation is a severe disease of the crop which is widely spread in almost all mango-growing regions worldwide $(6,13,14,25,28)$. Symptoms of disease include misshapen growth of both vegetative and productive parts of the tree $(12,13,18$, $25,26,29)$. Vegetative malformation includes hypertrophy of young shoots, shorter internodes, dwarfed malformed leaves, and an overall tightly bunched appearance of infected shoots. Inflorescence malformation includes short, thick, and branched axes of the inflorescence, larger flowers, and increased number of male flowers. Malformed inflorescences do not bear any fruit, hence the great yield losses caused by this disease $(13,18,22,25,28,33)$.

Several causal agents, all members of the genus Fusarium, have been associated with this disease. Fusarium mangiferae Britz, M. J. Wingf. \& Marasas (previously recognized as $F$. moniliforme J. Sheld. and later as F. moniliforme var. subglutinans Wollenw. \& Reinking) has the largest geographic distribution (16). Koch postulates were completed with this species for the first time in $1966(3,5,7,14,19,20,22,26,27,35,36)$, and also recently with $F$. sterilihyphosum Britz, Marasas \& M. J. Wingf. (16), which is distributed in Brazil and South Africa (3,20). Likewise, pathogenicity tests were also conducted with a new phylogenetic lineage that is closely related to $F$. sterilihyphosum and has been isolated to date only from Brazil (16). Another recent study from Mexico reported the successful completion of Koch postulates with local strains of Fusarium spp., which were different from $F$. mangiferae and F. oxysporum; however, further work is required to compare this species to $F$. sterilihyphosum (30). Pathogenicity

Corresponding author: S. Freeman; E-mail address: freeman@volcani.agri.gov.il

doi:10.1094/PHYTO-99-6-0775

(C) 2009 The American Phytopathological Society tests were not conducted for two other taxa, Fusarium sp. nov. and $F$. proliferatum Samuels, Nirenberg \& Seifert (teleomorph: Gibberella intermedia), reported to affect mango in Malaysia $(3,20)$.

Epidemiology of mango malformation is not well understood $(13,25,26)$. A recent study on dispersal patterns of conidia of $F$. mangiferae suggests aerial dispersal as the primary mechanism for fungal dissemination (9) but further information regarding location of infection sites, infection processes, and colonization within the tree is still unknown. A previous study reported that the presence of Aceria mangiferae, the mango bud mite, within buds increased frequency and severity of bud colonization by the pathogen, indicating that the bud mites may enhance fungal infection (8). Because the pathogen was detected in malformed panicles and vegetative shoots but rarely detected in branches (24), it was postulated that vegetative and floral buds are probably the primary sites for infection (26); however, this needs further support. Root infection was reported to cause symptoms at the root collar and the canopy but, because those studies lacked appropriate controls, the results are questionable (25). Recently, Youssef et al. (38) reported that inoculum can survive in soil although survival of bare conidia declined very rapidly under summer conditions. Furthermore, naturally infected panicles that were buried $30 \mathrm{~cm}$ under the soil surface resulted in a decline of $80 \%$ in inoculum survival after 24 weeks (38), further indicating that the pathogen is not a typical soilborne fungus.

Within-tree spread of the pathogen is poorly understood (25). The pathogen was isolated frequently from malformed tissue but infrequently from supporting branches $(6,24,27)$; therefore, it was concluded that systemic colonization of mango behind the apical parts of the plant might be rare. Ploetz (25) suggested that the infrequent infections found in old branches could be remnant 
infections that were left behind as the shoot grew, and that basipetal colonization of mango is rare. When vegetative malformed mango seedlings, growing under infected trees, were sampled for detection of the pathogen, fungal colonization was concentrated mainly in the apical meristem sections (97\%) and gradually declined to $5 \%$ colonization in the roots (38). This study further indicated that infections are not systemic, with infections of apical meristems most likely originating and disseminating from malformed panicles (38).

The objectives of this study were to (i) evaluate conditions affecting germination and growth of $F$. mangiferae conidia and hyphae, (ii) determine the location of infection sites in the tree and the colonization pattern within infected tissue, and (iii) assess annual infection dynamics in the orchard by determining when conidia land and infect trees.

\section{MATERIALS AND METHODS}

Plants and fungal isolates. Two-year-old mango seedlings, susceptible to malformation (Maya cultivar grafted on rootstock $13 / 1$ ), planted in 10-liter pots containing local red loam, were used in inoculation experiments. Two isolates were used throughout the experiments; a local representative wild-type $F$. mangiferae isolate no. 34 (MRC 7560) (34), and a green fluorescent protein (gfp)-marked isolate, designated as gfp-1 (8). The monoconidial cultures were maintained on potato dextrose agar (PDA) (Difco Laboratories, Detroit) at $25^{\circ} \mathrm{C}$. Conidial suspensions were obtained by adding sterile water to the cultured plates, mixing the suspension, and filtering it through a four-layered gauze pad. For all orchard-related experiments, naturally diseased cv. Haden trees were sampled from the Volcani experimental orchard in Bet Dagan.

Isolation and identification of the fungus from stem and root tissues was performed as follows: plant material was sectioned into 5-mm-longitudinal pieces, surface sterilized for $10 \mathrm{~s}$ in $70 \%$ ethanol, then $3.5 \mathrm{~min}$ in $3 \%$ sodium hypochlorate, and plated on a Fusarium-selective medium (21). After 6 days, fungal colonies that resembled Fusarium spp. were transferred to PDA, identified by morphology under a microscope, and verified by using a molecular polymerase chain reaction (PCR) method with specific primers (39). Isolation of the gfp- 1 isolate from plant tissue was conducted by plating material on PDA medium amended with hygromycin at $50 \mu \mathrm{g} / \mathrm{ml}$.

Conditions affecting germination and growth of $\boldsymbol{F}$. mangiferae. Conidial suspensions $\left(5 \times 10^{4}\right.$ conidia $\left./ \mathrm{ml}\right)$ of isolate no. 34 were incubated for $16 \mathrm{~h}$ under seven temperatures of 5 to $35^{\circ} \mathrm{C}$ at $5^{\circ} \mathrm{C}$ increments. Lactophenol Cotton Blue (Sigma-Aldrich, St. Louis) stain was added to each conidial suspension at the end of the incubation period. Percent conidial germination was calculated for 30 conidia per treatment (temperature) after lightmicroscopic observations ( $\times 20$ magnification; Wild, Heerbrugg, Switzerland). The experiment was conducted three times.

Measurements of colony growth were determined by placing fresh $F$. mangiferae fungal disks of $4.5 \mathrm{~mm}$ in the center of 90-mm PDA plates. Plates were incubated at each temperature as described. After 5 days, the new colony growth area was measured. Each treatment was repeated two times, and mean growth area and standard error were calculated. The experiment was conducted two times.

Conidial germination of $F$. mangiferae was observed on GLASSTIC slides with grids (HYCOR Biomedical, Inc., Garden Grove, CA). Drops of $10^{4}$ conidia/ml $(20-\mu \mathrm{l})$ were placed into the slide cells and maintained inside a moist chamber on a moistened filter paper at $25^{\circ} \mathrm{C}$. Every hour, between 0 and $8 \mathrm{~h}$ of wetness exposure, one slide bearing three slide cells with conidia was removed from the moist chamber, placed in front of a vent for 15 min to dry, and then transferred to a dry chamber containing silica gel. After $8 \mathrm{~h}$, when all drops were dry, a drop of Lacto- phenol Cotton Blue was placed in each slide cell and percent germination of conidia was calculated as previously described. In all experiments described above, each treatment was repeated three to four times and the experiments were conducted twice. Means and standard errors were calculated for each treatment using JMP 5.0.1 software (SAS Institute Inc., Cary, NC) and the data analyzed using SigmaPlot 2001 software (SPSS, Chicago).

Location of infection site. Potted plants that were fumigated twice with Dichlorvos (Divipan, 1,000 g/liter; Makhteshim-Agan, Omer, Israel), using a fumigator (Hagarin, Yavne, Israel) to ensure they were void of mites and insects, were cultivated in a growth chamber under controlled temperatures at $25 \pm 3^{\circ} \mathrm{C}$. The base of the stem was ringed with a water-based adhesive (Rimifoot liquid; Rimi Chemical Co. Ltd., Petach Tikva, Israel) to prevent infestation by ambulant arthropods. Different plant organs (apical buds, lateral buds, branches, and leaves) were inoculated with the gfp-1marked isolate and with a water control by placing $20 \mu \mathrm{l}$ of conidial suspension $\left(5 \times 10^{6}\right.$ conidia/ml of $0.1 \%$ water agar $)$ on the tested organs. The organs were then covered overnight with plastic bags that were sprayed with water. There were 20 replicates per organ, and the trial was performed twice-trial 1 in June to July 2007 and trial 2 in April to May 2006. One month postinoculation, the plant organs were dissected, surface sterilized, and plated on PDA medium amended with hygromycin at $50 \mu \mathrm{g} / \mathrm{ml}$. After 5 days, F. mangiferae-transformed colonies that developed were enumerated and mean numbers of colonized plant organs were determined. A $\chi^{2}$ test was used to determine levels of significance between the plant organs colonization $(P<0.05)$.

Potted plants were grown in a chamber under constant temperature conditions of $25 \pm 3^{\circ} \mathrm{C}$ for a period of 19 weeks. The plants were inoculated by pouring a 1-liter conidial suspension of isolate no. $34\left(10^{10}\right.$ conidia/ml $)$ into the growth medium of the pots. Five plants treated with water served as negative controls. After 19 weeks, plants were uprooted and both roots and upper stems were sampled for detection of fungal colonization. For this purpose, five root segments per pot, $2 \mathrm{~cm}$ in length, were sampled randomly. In addition, all upper stems were sectioned into 10 segments. Each segment was then subsectioned and one 5-mm piece was sampled. All pieces were surface sterilized and plated on PDA medium, and percent colonization of plants' roots and stems was determined per potted plant. The trial was conducted twice-trial 3 in June to July 2007 and trial 4 in April to May 2006. Each trial had 10 replicates (plants), and means of F. mangiferae-colonized pieces in the roots and stems were calculated per experiment. An analysis of variance for repeated experiments was used to determine levels of significance between root and stem colonization.

Colonization pattern within the host tissue. Pattern of colonization was determined in naturally infected trees. Two groups of branches were sampled from infected trees in the Volcani experimental orchard. The first group was sampled from young growth tissue $\approx 1$ month old, termed "vegetative", and the second contained branches from third to fifth growth segments, $\approx 2$ years old, termed "woody". Branches were sectioned into 5-mm-long pieces from either the node areas containing lateral buds of the branch or from the internode areas. Pieces were surface sterilized, plated on Fusarium-selective medium, and assessed for fungal colonization, as described previously. The experiment was conducted twice: one experiment was set up in September 2004 and the second experiment was set up 4 years later in September 2008. Samples of 32 and 20 branches were taken in the first and second experiments, respectively. Percent colonization of sections out of total number of sections was calculated per branch for each of the node and internode tissues. Mean percentages and standard error of colonized sections were calculated. A $t$-test analysis was conducted to determine levels of significance between colonization incidences in the nodes versus internode tissues. Data underwent arcsine and square root transformation before analysis. 
Infection dynamics. Dry malformed inflorescences ("dry debris") were sampled from the Volcani experimental orchard and were used as a source of inoculum for inoculating potted plants grown in a chamber under controlled temperature conditions of $25 \pm 3^{\circ} \mathrm{C}$. Before inoculations, samples of the debris were surface sterilized and placed on Fusarium-selective medium plates to verify that they contained viable inocula. Half of the buds in each trial were inoculated with the dry debris and the other half served as a control and remained noninoculated. Buds from the two groups (inoculated and noninoculated) were similar in size and location on the plant. Dry debris $(400 \mathrm{mg}$ ) were moistened with $400 \mu \mathrm{l}$ of tap water and placed on top of each treated, closed apical bud. After inoculation, buds were sprayed with tap water till run-off. Ten days later, before bud break, all apical buds were removed, surface disinfected, and plated on Fusarium-selective medium. The trial was conducted three times on six potted plants bearing a total of 70,76, and 96 buds per trial for trial 1, trial 2, and trial 3, respectively. Percent colonized buds for the inoculated and control treatments was calculated and a $\chi^{2}$ analysis was performed using JMP 5.0.1 software (SAS Institute Inc.).

In order to estimate the seasonal dynamics of airborne conidia of $F$. mangiferae landing and infecting trees in the orchard, leaves of mango trees (cv. Haden) were sampled monthly during March to September in 2008. Nine 10-mm-diameter disks were sampled randomly from 30 leaves sampled from three trees. The leaf disks were plated on Fusarium-selective medium and removed $16 \mathrm{~h}$ later. This method of 16-h blotting of the disks ensured that propagules of $F$. mangiferae, if present on the surface of the leaf
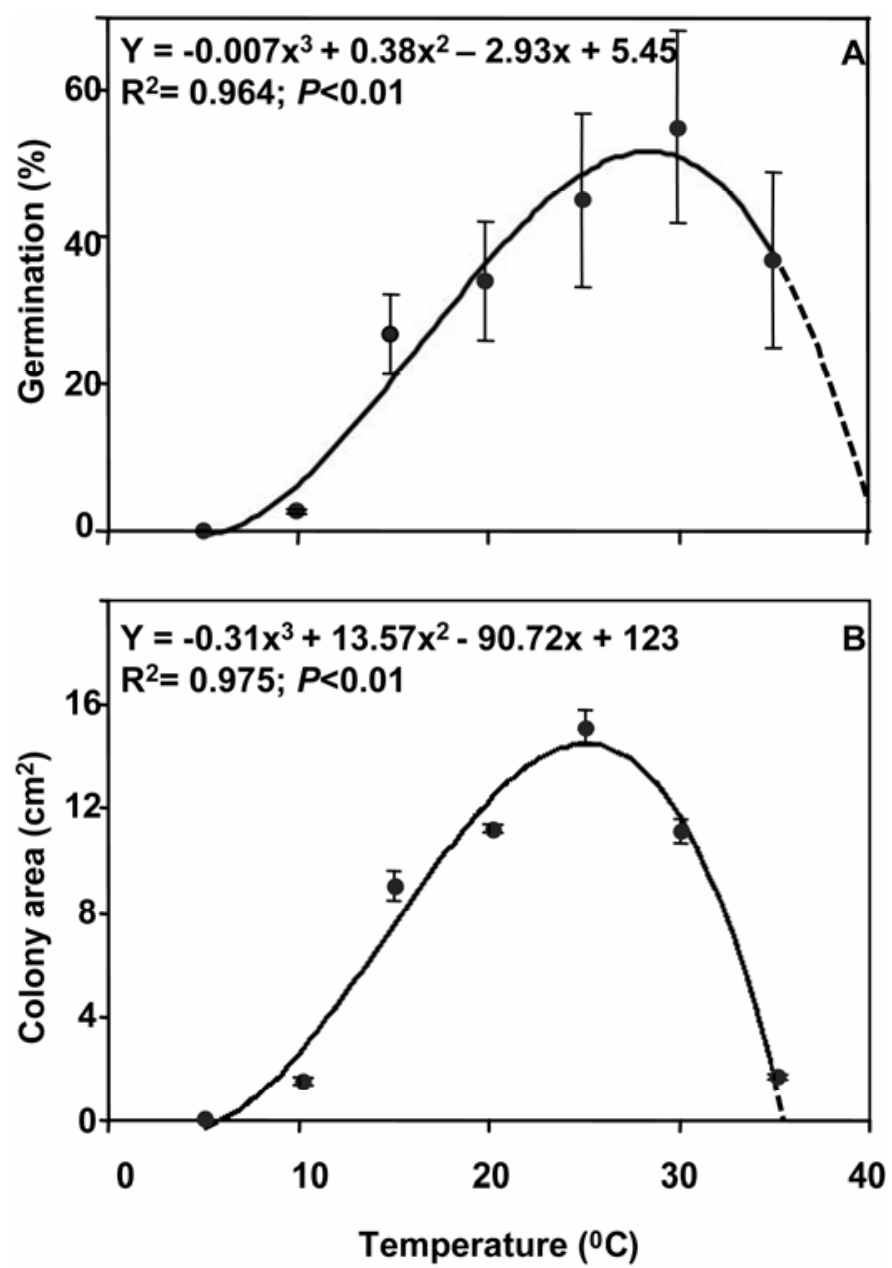

Fig. 1. Effect of temperature on $\mathbf{A}$, conidial germination and $\mathbf{B}$, fungal colony growth of Fusarium mangiferae. Vertical lines represent standard error of the mean. Dashed line represents extrapolation of the regression equation. disk, germinated on the medium. Plates were incubated for 5 days at $25 \pm 3^{\circ} \mathrm{C}$ for development of typical Fusarium colonies. The incidence of leaf disks bearing $F$. mangiferae propagules on their surfaces was calculated, as well as the mean and standard error of the incidence of colonized disks per sampling date. A TukeyKramer analysis was used to determine differences in leaf coverage between sampling dates $(P<0.05)$.

The timing of airborne infections in the Volcani orchard was assessed every vegetative flush during three consecutive years in the following months: June, July, and September 2005; May, June, July, August, and September 2006; and May, June, July, August, October, and November 2007. Apical and lateral buds were dissected from each of 60 vegetative (1-month-old) branches sampled in each month. Sections (5-mm) were disinfected, plated, and evaluated for fungal colonization. The branches were then grouped into four categories: (i) those that were not colonized with $F$. mangiferae at all, (ii) those that were colonized only in the apical buds, (iii) those that were colonized only in the lateral buds, and (iv) those that were colonized in both the apical and lateral buds. For each month, percent branches which were colonized only in the apical buds was calculated. The mean average colonization per month over a 3-year period (2005 to 2007) \pm standard error was determined.

\section{RESULTS}

Conditions affecting germination and growth of $\boldsymbol{F}$. mangiferae. Both conidial germination and colony growth required temperatures $>5^{\circ} \mathrm{C}$ in order to commence the germination and growth processes. Moreover, both conidial germination and colony growth increased with a corresponding elevation in temperature and reached a peak at optimal temperatures of 28 and $25^{\circ} \mathrm{C}$, respectively. Extrapolation of the presented data suggests that the maximum temperature for conidial germination is $\approx 41^{\circ} \mathrm{C}$ and that for colony growth is $\approx 36^{\circ} \mathrm{C}$ (Fig. 1).

A minimum 2-h wetness period was required for the beginning of the conidial germination process at $25^{\circ} \mathrm{C}$, increased with increasing exposure to wetness, and reached a peak after $8 \mathrm{~h}$ of wetness (Fig. 2).

Location of infection site. Artificial inoculations of apical and lateral buds, branches, and leaves of potted plants resulted in high incidence of fungal colonization in buds, predominantly the apical buds (Table 1). In trial 1, all apical buds were colonized with the pathogen, significantly less in lateral buds, while very low and insignificant levels of colonization were detected in branches and leaves. Similar results were obtained in trial 2 but were characterized by less overall colonization incidence. The apical buds were the most colonized organ, followed by lateral buds, while branches and leaves remained uncolonized (Table 1).

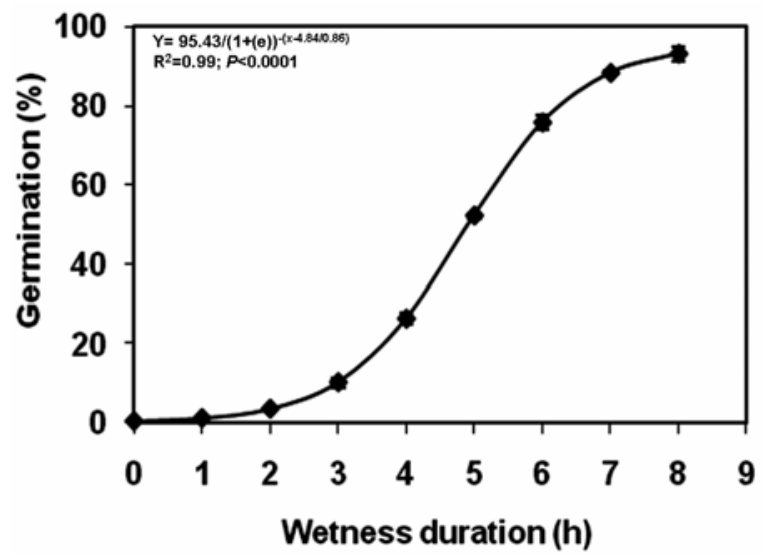

Fig. 2. Effect of wetness duration on germination of conidia of Fusarium mangiferae. Vertical lines represent standard error of the mean. 
In the soil inoculation trials, the pathogen was detected in the roots of inoculated soil. Nineteen weeks postinoculation, 60.2 and $37.8 \%$ of the root segments were colonized by $F$. mangiferae in trials 3 and 4, respectively, but not in aboveground parts of the plants (Table 1). In addition, disease symptoms were not observed in the aboveground plant parts. All water-inoculated control plants were disease free and the pathogen was not detected in the roots or the upper parts of the plant. Furthermore, the pathogen was not detected in aboveground parts of soil inoculated plants, 52 weeks after inoculation (data not shown).

Colonization pattern within the host tissue. Percent colonization of $F$. mangiferae within naturally infected branches was significantly higher in node sections containing lateral buds than in internode sections (between lateral buds), where colonization was negligible in both groups of sampled branches. Percent colonization within node sections of vegetative branches was $12.0 \pm 3.7 \%$, significantly higher than $0.1 \pm 0.1 \%$ within internode sections. Similar results were observed for woody branches, where a significantly higher percentage of colonization $(6.8 \pm$ $2.3 \%$ of the sections) was detected in the node sections compared with that observed in the internode sections $(1.3 \pm 0.7 \%)$.

Infection dynamics. When dry, malformed inflorescences were used to inoculate apical buds of potted plants, the pathogen was detected in 52.6 and $20.1 \%$ of the inoculated buds of trials 1 and 3 , respectively, which was significantly higher than that detected in the noninoculated untreated controls (Table 2). In trial $2,13.9 \%$ colonization was detected in the inoculated buds, which was higher but not significantly different than that of $2.8 \%$ colonization detected in the untreated control.

$F$. mangiferae was detected on the surface of mango leaves sampled from infected trees throughout the sampling period. The incidence of leaf disks bearing propagules of $F$. mangiferae on their surfaces varied over time, peaking in June and July and decreasing in August and September 2008 (Fig. 3).

One-month-old branches started to develop in the orchard in late spring (May) and continued to appear until early autumn (November). Incidence of 1-month-old branches colonized with $F$. mangiferae in the apical bud but not in the lateral buds during the 3 -year period of the survey was the highest in May and June, reaching 8 to $10 \%$ colonization of the total number of sampled branches (Fig. 4). Incidence of colonized branches decreased in the following months of July to September, where $\approx 2 \%$ of all branches were colonized only in the apical bud tissue. During October and November, only a very low incidence of colonized branches was detected (Fig. 4).

\section{DISCUSSION}

Very little or no information has been published regarding conditions affecting germination and growth of $F$. mangiferae and the infection patterns of this pathogen. Conidia of $F$. mangiferae are likely to be the most prevalent propagules resulting in spread of the pathogen (9); therefore, evaluating conditions affecting their germination and growth may contribute to a better understanding of the infection process. Low temperatures $\left(<5^{\circ} \mathrm{C}\right)$ did not permit conidial germination and colony growth. Optimal temperatures for growth and germination vary between different Fusarium spp. $(15,31)$, while the optimal temperature for germination and growth of $F$. mangiferae conidia was 28 and $25^{\circ} \mathrm{C}$, respectively. Therefore, this temperature range does not appear to be a limiting factor in seasonal disease development of mango malformation in mango cultivation areas worldwide. In most fungal pathogens, successful infection depends on a minimal duration of wetness (11) provided in the form of rain or dew $(4,17,32,37)$. A minimum of $2 \mathrm{~h}$ of wetness was required before conidial germination and an optimum of $8 \mathrm{~h}$ of wetness was recorded. This was similar for macroconidia of $F$. graminearum requiring a minimum of 2 to $6 \mathrm{~h}$ of $100 \%$ relative humidity for germ tube emergence (2). Therefore, moisture is also not a restricting factor for infection under field conditions in Israeli orchards, where these requirements are routinely obtained during the rainy season (October to March) or during heavy dew events commonly occurring during the dry season, May to August $(1,10)$, the periods when infection may occur in the orchard.

Location of infection sites is assumed to be the apical buds but this lacked substantial evidence (26). Results of the current study support this assumption and demonstrated that the pathogen was capable of establishing in the buds following inoculation of the buds themselves but failed when the soil, branches, or leaves were inoculated. Differences between trials in incidence of colonization might be attributed to different temperature conditions occurring in the different months when the trials were conducted. Temperatures in trials 1 and 3 were 3 to $6^{\circ} \mathrm{C}$ higher than those of trials 2 and 4. Our results support those of Youssef et al. (38) that infections in young seedlings growing under malformed, mature trees were affected via the apical meristem. F. mangiferae does not form chlamydospores (15), inoculum survival declined rapidly in the soil (38), and the pathogen was not detected beyond the root tissue of soil-inoculated plants; therefore, it appears that infec-

TABLE 2. Incidence of colonization by Fusarium mangiferae of apical buds of potted plants following artificial inoculation with dry debris of naturally infected malformed inflorescences from the Volcani experimental orchard

\begin{tabular}{lccc}
\hline & \multicolumn{3}{c}{ Colonization $(\%)^{\mathrm{z}}$} \\
\cline { 2 - 4 } Treatment & Trial 1 & Trial 2 & Trial 3 \\
\hline Inoculated & $52.6 \mathrm{a}$ & $13.9 \mathrm{a}$ & $20.1 \mathrm{a}$ \\
Untreated control & $0.0 \mathrm{~b}$ & $2.8 \mathrm{a}$ & $0.0 \mathrm{~b}$ \\
\hline
\end{tabular}

${ }^{\mathrm{z}}$ Percentages of colonized buds per experiment were calculated out of a total of 70,76 , and 96 buds in trials 1,2 , and 3 , respectively. Different letters within each trial column denote statistical significance of $P<0.05$ using a $\chi^{2}$ test.

TABLE 1. Incidence of colonization of mango plants after artificial inoculations of various organs or of soil with Fusarium mangiferae

\begin{tabular}{|c|c|c|c|c|}
\hline \multirow[b]{2}{*}{ Inoculation site, isolation from } & \multicolumn{4}{|c|}{ Colonization $(\%)^{\mathrm{z}}$} \\
\hline & Trial 1 & Trial 2 & Trial 3 & Trial 4 \\
\hline \multicolumn{5}{|l|}{ Organ } \\
\hline Apical buds & $100.0 \mathrm{a}$ & $20.0 \mathrm{a}$ & $\ldots$ & $\ldots$ \\
\hline Lateral buds & $60.0 \mathrm{~b}$ & $5.6 \mathrm{ab}$ & $\ldots$ & $\ldots$ \\
\hline Branches (internode sections) & $5.0 \mathrm{c}$ & $0.0 \mathrm{~b}$ & $\ldots$ & $\ldots$ \\
\hline Leaves & $0.0 \mathrm{c}$ & $0.0 \mathrm{~b}$ & $\ldots$ & $\ldots$ \\
\hline \multicolumn{5}{|l|}{ Soil } \\
\hline Roots & $\ldots$ & $\ldots$ & $60.2 \mathrm{a}$ & $37.8 \mathrm{a}$ \\
\hline Stems (internode and node sections) & $\ldots$ & $\ldots$ & $0.0 \mathrm{~b}$ & $0.0 \mathrm{~b}$ \\
\hline
\end{tabular}

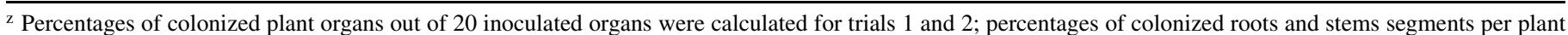
out of 5 and 10 segments sampled, respectively, were calculated for trials 3 and 4 and averages of colonization incidence were calculated per 10 plants. Different letters within columns of trials 1 and 2 denote statistical significance of $P<0.05$ using a $\chi^{2}$ test; different letters within columns of trials 3 and 4 denote statistical significance of $P<0.0001$ using one-way analysis of variance. 
tions through the roots are not plausible, indicating that buds, predominantly apical buds, are the main sites of infection.

In this study, we have demonstrated how foliar coverage in mango orchards during 2008 occurred mostly in June and July (Fig. 3), possibly following a peak in aerial dissemination of conidia of $F$. mangiferae. As previously described (9), aerial dissemination of $F$. mangiferae occurs in Israel during a rather narrow period of the year. Most of the surface area in mango orchards is occupied by leaves and, because conidia disseminate passively in the air (9) and arbitrarily land on trees, it is likely that most of the leaves are covered with this form of inoculum. How, then, do conidia reach their infection site, the apical buds? One possible way is by landing randomly on apical buds, although the probability for this event to take place is rather small. Another route is via transport of conidia on the bodies of mango bud mites (A. mangiferae) from their arbitrary landing sites on leaves into buds, the exclusive habitat of the mite (8). This route of transport is available year round because $A$. mangiferae mites are present in apical buds of mango throughout the year and disperse from them when bud break commences (8); however, inoculum on leaves is mostly abundant in June and July, when leaves are covered with fungal propagules. A third possible route, which is presented in the current study, is via dry, malformed inflorescence debris falling on top of apical buds that form, together with surrounding leaves, a funnel-like structure. Levels of colonization incidence of apical buds following inoculation with dry, malformed debris varied between the three trials. These differences can be explained by the inoculation methodology. As mentioned in the text, $400 \mathrm{mg}$ of dry debris were moistened and placed on top of each treated apical bud; also, before inoculations, samples were verified to contain viable inocula but were not quantified in each trial. The latter fact most likely contributed to the differences between trials. The low incidence of colonization detected in the untreated control of trial 2 may have occurred as a result of contamination during inoculation of neighboring treated and untreated buds. Dry, malformed inflorescence debris falling on top of apical buds is a common phenomenon in mango orchards. Unlike fresh, healthy inflorescences that yield fruitlets, with most dropping after fruit set, dry, malformed "mummy-like" inflorescences may remain and overwinter on the trees (if not removed by sanitation), providing a plausible route of inoculum transfer year round. When dry debris were placed over apical buds of potted plants and moistened (mimicking rain events), the pathogen was capable of infecting bud tissue, demonstrating that debris containing conidia may constitute a source of inoculum.

In order to determine the seasonal pattern of aerial infections, leaves and branches were sampled monthly from the orchard and monitored for the presence of the pathogen. The incidence of leaf disks containing $F$. mangiferae propagules on their surface was the highest during June and July, where 20 to $25 \%$ of the disks bore fungal propagules on their surface. In addition, colonization of the pathogen was detected in apical but not lateral buds of 1-month-old branches, further indicating the mode of aerial infection. It was assumed that these buds were infected by airborne conidia that originated from malformed inflorescences rather than systemic infections from within the tree. Incidence of branches

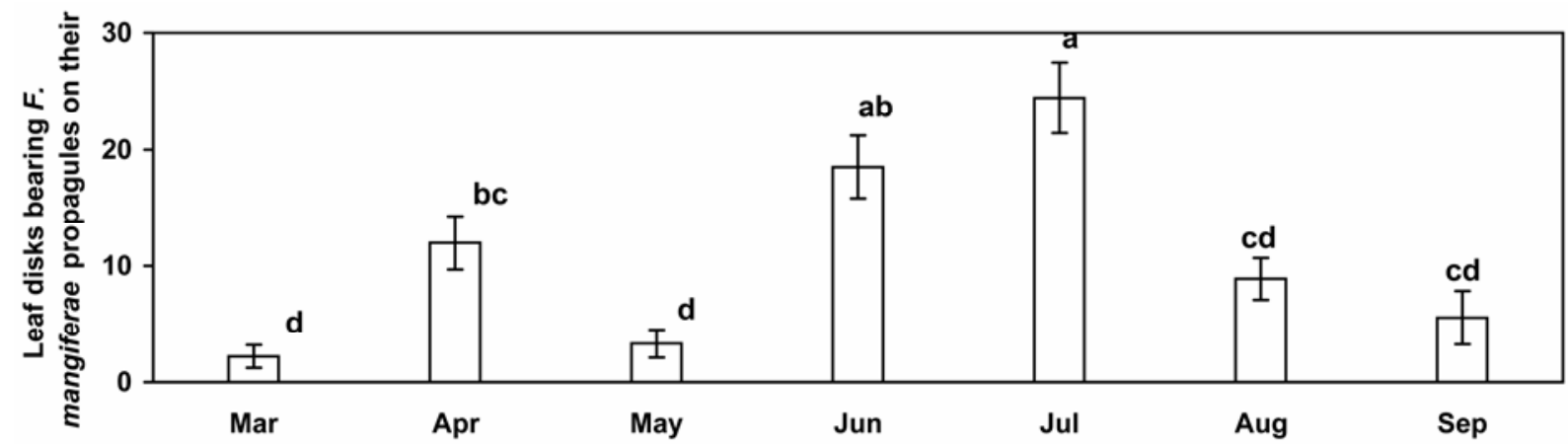

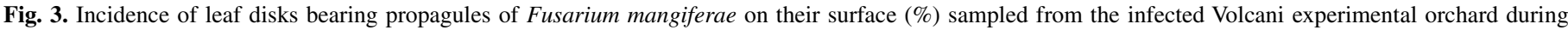

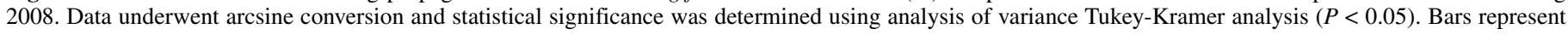
standard error of the mean.

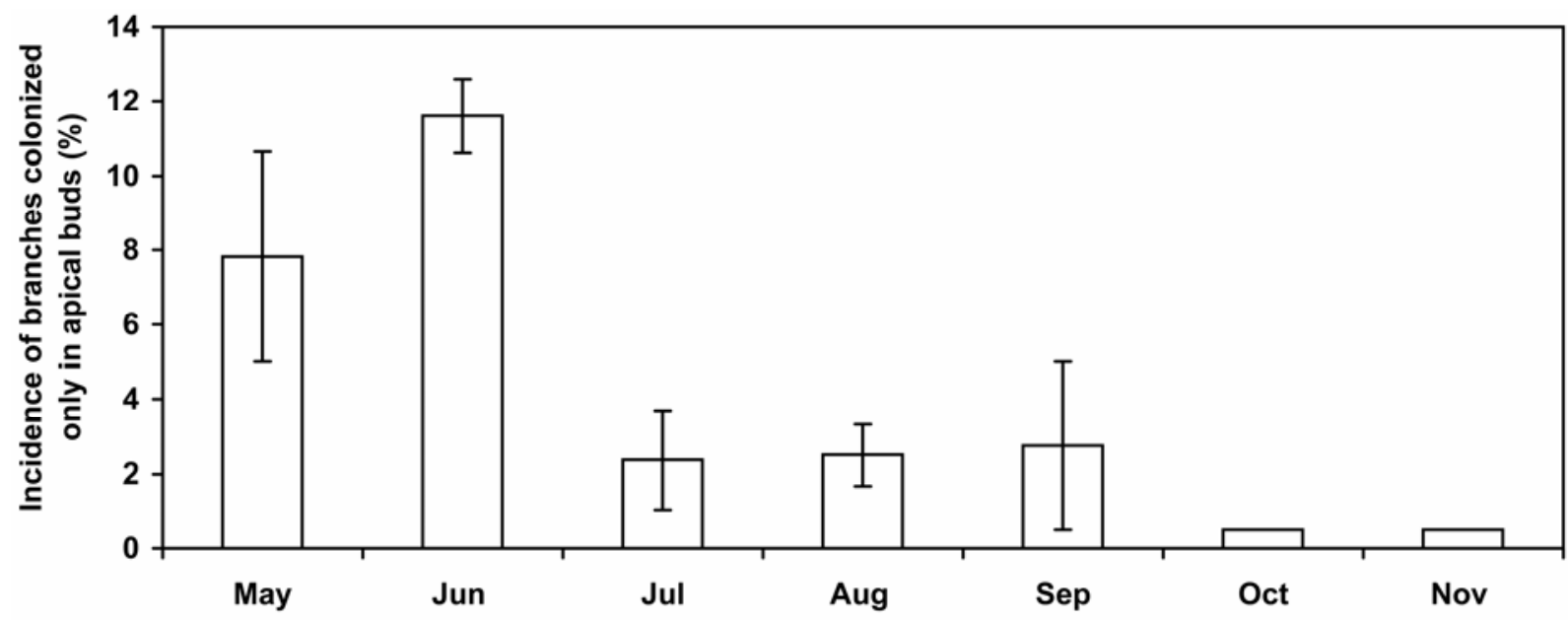

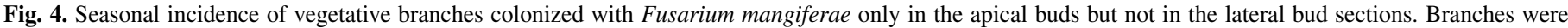

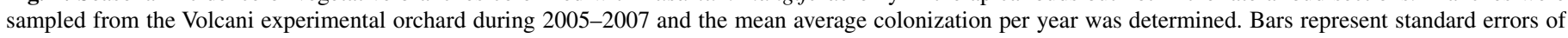
the mean. 
colonized in the apical but not in the lateral buds was highest in May and June, which coincides with a previous study reporting a peak of malformed inflorescences and conidial dissemination in an infected mango orchard in Israel (9). Another study of seasonal infection dynamics in mango orchards in Mexico detected three annual peaks of disease incidence, which occurred during and immediately following the flowering season (22).

In this study, we observed colonization of the pathogen in node sections of both vegetative and woody branches. Several studies previously reported isolation of the pathogen from malformed tissue but not from supporting branches $(6,24,27)$, concluding that systemic colonization of mango behind apical portions of the plant might be rare. According to our results, this conclusion might be deceiving because the pathogen appears to colonize the node sections of the sampled branches but the internode sections of the branches, which do not contain the pathogen, may have been sampled instead. Colonization of the node sections (lateral buds) in branches can also explain the "infrequent infections found in old branches" (25), which suggests a noncontinuous colonization pattern within the tree.

In summary, a possible cycle for mango malformation disease caused by F. mangiferae is proposed (Fig. 5). Malformed inflorescences and malformed vegetative growth serve as a source of inoculum. Inoculum from infected panicles and malformed vegetative tissue disseminate passively in the air as conidia (9) or fall from dry, malformed inflorescences as dry debris. Most of the conidia fall on the mango canopy and reach the infection site by at least three different routes: falling by chance on the apical bud, being vectored on the body of the bud mite A. mangiferae (8), or via conidia in dry debris falling into the funnel-like structure of the apical buds. Other possible routes, not tested in this study, could also assist conidia in reaching the apical bud (e.g., transport of conidia in dew droplets or splash dispersal of conidia from leaves to buds, although the latter route probably does not occur in Israel due to lack of rains in the early summer months when conidial dissemination takes place). Conidial germination and infection of apical buds may occur if appropriate conditions are met: temperatures of 5 to $41^{\circ} \mathrm{C}$ accompanied by at least $2 \mathrm{~h}$ of wetness. Moderate temperatures of 15 to $30^{\circ} \mathrm{C}$ and longer durations of wetness $>3 \mathrm{~h}$ may accelerate the infection process. Presence of $A$. mangiferae inside the buds assists fungal penetration and increases frequency and severity of infection (8). After penetration, the pathogen colonizes the bud tissue but does not progress beyond this point. Apical buds could either differentiate into a reproductive inflorescence following appropriate exposure to cold temperatures or remain vegetative and develop into a young shoot (23). Inflorescences from a colonized bud may emerge malformed, probably due to a build-up of the pathogen until an infection threshold is met $(25,26)$. Alternatively, when a young shoot emerges from an infected apical bud, the pathogen may colonize the apical or lateral buds of the young shoot, then remain localized and dormant in buds until bud break. This young shoot may show symptoms of vegetative malformation or bear the pathogen within bud tissue without showing typical disease symptoms.

This study has shed light on infection dynamics and colonization patters of $F$. mangiferae in infected mango trees. Protecting apical buds from airborne infections and maintaining strict

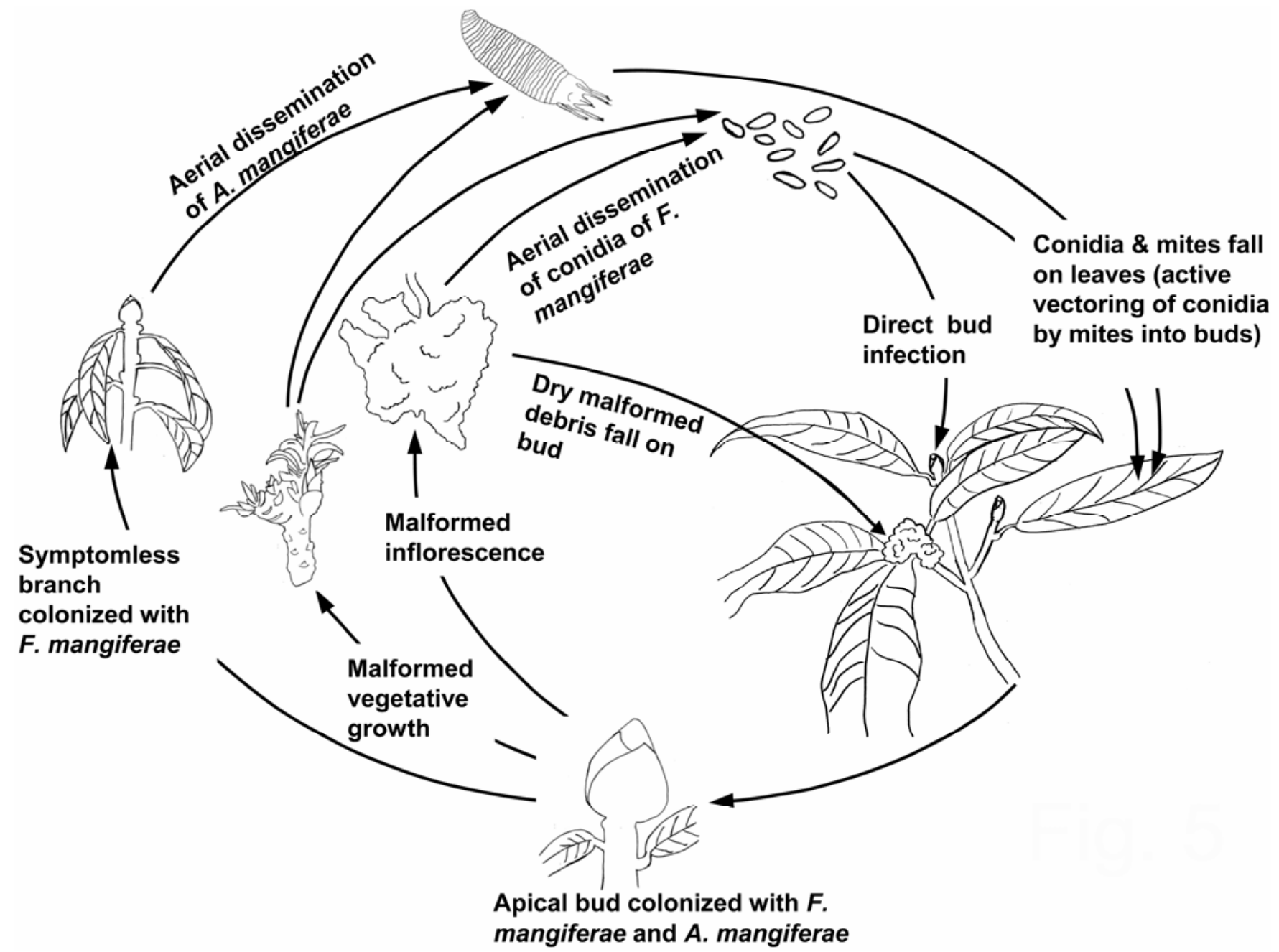

Fig. 5. Proposed cycle of mango malformation disease caused by the pathogen Fusarium mangiferae (A. mangiferae = Aceria mangiferae). 
sanitation in the orchard by immediate removal of malformed tissues may contribute to an improved management strategy for mango malformation disease.

\section{ACKNOWLEDGMENTS}

This research was supported in part by grant no. 132-0972 from the Chief Scientist of the Israeli Ministry of Agriculture, and by the Bureau for Economic Growth, Agriculture, and Trade, U.S. Agency for International Development, under the terms of the Middle East Regional Cooperation Program Award No. TA-MOU-02-M21-030, awarded to S. Freeman. We thank A. Zveibel, Y. Denisov, and M. Sharon for technical assistance.

\section{LITERATURE CITED}

1. Berkowicz, S., Beysens, D., Milimouk, I., Heusinkveld, Muselli, M., Wakshal, E., and Jacobs, A., 2004. Urban dew collection under semi-arid conditions: Jerusalem. In: Proc. Third Int. Conf. Fog, Paper E4, Fog Collection and Dew, Cape Town, South Africa.

2. Beyer, M., Röding, S., Ludewig, A., and Verreet, J. A. 2004. Germination and survival of Fusarium graminearum macroconidia as affected by environmental factors. J. Phytopathol. 152:92-97.

3. Britz, H., Steenkamp, E. T., Coutinho, T. A., Wingfield, B. D., Marasas, W. F. O., and Wingfield, M. J. 2002. Two new species of Fusarium section Liseola associated with mango malformation. Mycologia 94:722730.

4. Carisse, O., Bourgeois, G., and Duthie, J. A. 2000. Influence of temperature and leaf wetness duration on infection of strawberry leaves by Mycosphaerella fragariae. Phytopathology 90:1120-1125.

5. Chakrabarti, D. K., and Ghosal, S. 1989. The disease cycle of mango malformation induced by Fusarium moniliforme var. subglutinans and the curative effects of mangiferin-metal chelates. J. Phytopathol. 125:238246.

6. Crookes, C. A., and Rijkenberg, F. H. J. 1985. A literature review of the distribution, symptomology, cause and control of mango blossom malformation. S. Afr. Mango Grow. Assoc. Res. Rep. 5:15-24.

7. Freeman, S., Maimon, M., and Pinkas, Y. 1999. Use of GUS transformants of Fusarium subglutinans for determining aetiology of mango malformation disease. Phytopathology 89:456-461.

8. Gamliel-Atinsky, E., Freeman, S., Sztejnberg, A., Maymon, M., Ochoa, R., Belausov, E., and Palevsky, E. 2009. Interaction of Aceria mangiferae with Fusarium mangiferae, the causal agent of mango malformation disease. Phytopathology 99:152-159.

9. Gamliel-Atinsky, E., Sztejnberg, A., Maymon, M., Shtienberg, D., and Freeman, S. 2009. Inoculum availability and conidial dispersal patterns of Fusarium mangiferae, the causal agent of mango malformation disease. Phytopathology 99:160-166.

10. Goldreich, Y. 2003. The Climate of Israel: Observation, Research and Application. Kluwer Academic/Plenum Publishers, New York.

11. Huber, L., and Gillespie, T. J. 1992. Modeling leaf wetness in relation to plant disease epidemiology. Annu. Rev. Phytopathol. 30:553-577.

12. Kumar, J., and Beniwal, S. P. S. 1992. Role of Fusarium species in the etiology of mango malformation. Page 17 in: Int. Mango Symp. University of Florida, IFAS, Tropical Research and Education Center, and International Society for Horticultural Science, Miami Beach, FL.

13. Kumar, J., Singh, U. S., and Beniwal, S. P. S. 1993. Mango malformation: one hundred years of research. Annu. Rev. Phytopathol. 31:217-232.

14. Kvas, M., Steenkamp, E. T., Al Adawi, A. O., Deadman, M. L., Al Jahwari, A. A., Marasas, W. F. O., Wingfield, B. D., Ploetz, R. C., and Wingfield, M. J. 2008. Fusarium mangiferae associated with mango malformation in the Sultanate of Oman. Eur. J. Plant Pathol. 121:195-199.

15. Leslie, J. F., and Summerell, B. A. 2006. The Fusarium Lab Manual. Blackwell, Ames, IA.

16. Lima, C. S., Pfenning, L. H., Costa, S. S., Campos, M. A., and Leslie, J. F. 2009. A new Fusarium lineage within the Gibberella fujikuroi species complex in the main causal agent of mango malformation disease in Brazil. Plant Pathol. 58:33-42.
17. Luo, Y., and Michailides, T. J. 2001. Factors affecting latent infection of prune fruit by Monilinia fructicola. Phytopathology 91:864-872.

18. Majumder, P. K., and Sinha, G. C. 1972. Studies on the effect of malformation on growth, sex ratio, fruit set and yield of mango. Acta Hortic. 24:230-234.

19. Manicom, B. Q. 1989. Blossom malformation of mango. S. Afr. Mango Grow. Assoc. Yearb. 10:11-12.

20. Marasas, W. F. O., Ploetz, R. C., Wingfield, M. J., Wingfield, B. D., and Steenkamp, E. T. 2006. Mango malformation disease and the associated Fusarium species. Phytopathology 96:667-672.

21. Nash, S. N., and Snyder, W. C. 1962. Quantitative estimations by plate counts of propagules of the bean rot Fusarium in field soils. Phytopathology 73:458-462.

22. Noriega-Cantú, D. H., Téliz, D., Mora-Aguilera, G., Rodriguez-Alcazar, J., Zavaleta Mejía, E., Otero-Colinas, G., and Campbell, C. L. 1999. Epidemiology of mango malformation in Guerrero, Mexico, with traditional and integrated management. Plant Dis. 83:223-228.

23. Nunez-Elisea, R., Davenport, T. L., and Caldeira, M. L. 1996. Control of bud morphogenesis in mango (Mangifera indica L.) by girdling, defoliation and temperature modification. J. Hortic. Sci. 71:25-39.

24. Ploetz, R. C. 1994. Distribution and prevalence of Fusarium subglutinans in mango trees affected by malformation. Can. J. Bot. 72:7-9.

25. Ploetz, R. C. 2001. Malformation: a unique and important disease of mango, Mangifera indica L. Pages 233-247 in: Fusarium: Paul E. Nelson Memorial Symposium. B. A. Summerell, J. F. Leslie, D. Backhouse, W. L. Bryden, and W. L. Burgess. eds. American Phytopathological Society, St. Paul, MN.

26. Ploetz, R. C. 2003. Diseases of mango. Pages 327-363 in: Diseases of Tropical Fruit Crops. R. C. Ploetz, ed. CABI Publishing, Oxford, UK.

27. Ploetz, R. C., and Gregory, N. 1993. Mango malformation in Florida: Distribution of Fusarium subglutinans in affected trees, and relationships within and among strains from different orchards. Acta Hortic. 341:388394.

28. Ploetz, R., Zheng, Q. I., Vazquez, A., and Abdel Sattar, M. A. 2002. Current status and impact of mango malformation in Egypt. Int. J. Pest Manag. 48:279-285.

29. Prasad, A., Singh, N., and Singh, S. 1972. Mango malformation-a review of work done at the horticultural research institute, Saharanpur, India. Acta Hortic. 24:227-229.

30. Rodríguez-Alvarado, G., Fernández-Pavía, S. P., Ploetz, R. C., and Valenzuela-Vázquez, M. 2008. A Fusarium sp. different from Fusarium oxysporum and $F$. mangiferae is associated with mango malformation in Michoacán, Mexico. Plant Pathol. 57:781.

31. Rossi, V., Pattori, E., Ravanetti, A., and Giosue, S. 2002. Effect of constant temperature regimes on sporulation of four fungi causing head blight of wheat. J. Plant Pathol. 84:95-105.

32. Rotem, J. 1994. The Genus Alternaria. Biology, Epidemiology, and Pathogenicity. The American Phytopathological Society, St. Paul, MN

33. Sao Jose, A. R., Souza, S. E., Vega Pina, A., and Ataide, E. M. 2000. Incidence and severity of mango flower malformation in Bahia State, Brazil. Acta Hortic. 509:765-767.

34. Steenkamp, E. T., Britz, H., Coutinho, T. A., Wingfield, B. D., Marasas, W. F. O., and Wingfield, M. J. 2000. Molecular characterization of Fusarium subglutinans associated with mango malformation. Mol. Plant Pathol. 1:187-193.

35. Summanwar, A. S., Raychaudhuri, S. P., and Phatak, S. C. 1966. Association of the fungus Fusarium moniliforme Sheld. with the malformation in mango (Mangifera indica L.). Indian Phytopathol. 19:227-228.

36. Varma, A., Lele, V. C., Raychoudhuri, S. P., Ram, A., and Sang, A. 1974. Mango malformation: a fungal disease. Phytopathol. Z. 79:254-257.

37. Webb, D. H., and Nutter, F. W., Jr. 1997. Effects of leaf wetness duration and temperature on infection efficiency, latent period, and rate of pustule appearance of rust in alfalfa. Phytopathology 87:946-950.

38. Youssef, S. A., Maymon, M., Zveibil, A., Klein-Gueta, D., Sztejnberg, A., Shalaby, A. A., and Freeman, S. 2007. Epidemiological aspects of mango malformation disease caused by Fusarium mangiferae and source of infection in seedlings cultivated in orchards in Egypt. Plant Pathol. 56:257-263.

39. Zheng, Q., and Ploetz, R. 2002. Genetic diversity in the mango malformation pathogen and development of a PCR assay. Plant Pathol. 51:208-216. 